\title{
Heat transfer and efficiency of dual channel PVT air collector: a review
}

\author{
Ahmad Fudholi ${ }^{1}$, Muhammad Zohri' ${ }^{2}$, Ivan Taslim ${ }^{3}$, Fitrotun Aliyah ${ }^{4}$, Arthur Gani Koto \\ ${ }^{1}$ Solar Energy Research Institute, Universiti Kebangsaan Malaysia, Malaysia \\ ${ }^{2}$ Universitas Muhammadiyah Gorontalo, Indonesia \\ ${ }^{3}$ Department of Nuclear Engineering and Engineering Physics, Universitas Gadjah Mada, Indonesia
}

\begin{tabular}{|c|c|}
\hline Article Info & ABSTRACT \\
\hline Article history: & \multirow{10}{*}{$\begin{array}{l}\text { Solar energy is free, renewable and environment friendly and has been } \\
\text { widely used in electricity generation and thermal energy through } \\
\text { photovoltaic thermal (PVT) system. A PVT collector is a combination of } \\
\text { a PV panel and a thermal collector in a single unit to simultaneously generate } \\
\text { electricity and thermal energy. In this review, mathematical models for dual } \\
\text { channel PVT air collectors is presented. This review presents various } \\
\text { research and development, as well as heat transfer and thermal modelling of } \\
\text { dual channel PVT air collectors. Moreover, various mathematical models that } \\
\text { evaluate the performances base on energy and exergy analysis of dual } \\
\text { channel PVT air collectors are presented. Energy balance is the basic concept } \\
\text { in developing the mathematical models. Generally, steady-state one- } \\
\text { dimensional linear first-order differential equations were reported for } \\
\text { solution of mathematical model. Energy and exergy efficiencies of dual } \\
\text { channel PVT air collectors were } 22.5 \%-67 \% \text { and } 3.9 \%-58 \% \text {, respectively. }\end{array}$} \\
\hline Received Dec 8, 2018 & \\
\hline Revised Mar 1, 2019 & \\
\hline Accepted Apr 16, 2019 & \\
\hline Keywords: & \\
\hline Mathematical model & \\
\hline Photovoltaic & \\
\hline Renewable energy & \\
\hline Thermal & \\
\hline Thermal modelling & \\
\hline
\end{tabular}

Copyright (C) 2019 Institute of Advanced Engineering and Science. All rights reserved.

\section{Corresponding Author:}

Ivan Taslim,

Universitas Muhammadiyah Gorontalo,

Jl. Prof. Dr. H. Mansoer Pateda, Pentadio Tim., Telaga Biru, Kota Gorontalo, Gorontalo 96181, Indonesia.

Email: ivantaslim@umgo.ac.id

\section{INTRODUCTION}

Currently, fossil fuels are scarce and expensive, and its future cost and availability are uncertain. Hence, the usage of solar energy in drying of agricultural products will probably increase and further become economically feasible in the near future. Solar energy is a major renewable energy source that has the potential to supply daily energy consumption without polluting the environment. Solar radiation can be converted into electrical and thermal energies by using a photovoltaic (PV) panel and solar collector. The concept of combining a PV with solar thermal collector to obtain electrical and heat energy is not new but has gained limited reasearch attention. Considering the declining supply of energy sources and the increase in their usage, photovoltaic thermal (PVT) technology is eliciting gaining considerable interest. A PVT collector is a combination of a PV panel and a thermal collector in a single unit to simultaneously generate electricity and thermal energy. The main components of a PVT collector are PV panel, absorber, working fluid, and insulator. PVT solar collectors convert solar radiation directly into electrical and thermal energies. A PVT air collector consists of a PV panel and a thermal collector system. The system can produce electrical energy directly converted from sunlight, extract heat from the PV panel and warm the air flow inside the collector [1]-[13].

Tonui and Tripanagnostopoulos [14] developed a simple analytical model using the Fortran90 programming language, based on the energy balance equations between the PVT components, airflow and the ambient and validated against experimental data. This model used the program which uses iterative process to fix the initially guessed unknown parameters accurately and to converge after a few iterations. 
This model proved to indicate the difference between the predicted values and experimental data for air outlet temperature to be less than $1^{\circ} \mathrm{C}$. Tonui and Tripanagnostopoulos [15] proved that the air outlet temperature reduces with increasing channel depth. It was found that the fin system results in production of higher outlet temperature than the thin metal sheet and conventional air collector system for any channel depth. This is due to the increased heat extraction by the fins and the thin metal sheet system gives slightly higher outlet temperature than the conventional air collector system due to increased heat exchange surface. Furthermore, they also verified that the thermal and electrical efficiency reduce with increasing channel depth. The thermal efficiency reduced due to the reduced flow rate while the electrical efficiency decreased due to the increase in PV temperature as the depth increased. It was also found that the fin system performed better, for both thermal and electrical, than the other two systems. The thin metal sheet system gave better thermal energy but marginally better electrical efficiency than conventional air collector system.

The objective of this review is to describe types of PVT air collectors. In addition, to present some of the published research papers of PVT air collectors during the year 2010-2019. In this review, also presented heat transfer and energy modelling of dual channel PVT air collectors.

\section{STUDIES CONDUCTED ON PVT AIR COLLECTORS IN 2010-2019}

Overview of studies on PVT solar air collectors are reviewed. Various types of PVT air collectors have been designed and evaluated experimentally and theoretically. These collectors are generally classified according to the air flow pattern, that is, below the absorber, whether air flows above the absorber, on both sides of the absorber, in single and in double pass. The performances of PVT air collectors can be evaluated through economic and environmental impact analyses. Enviro-economic and exergo-economic analyses of PVT air collectors were also studied. In addition, researchers have also studied environmental-economicexergy-energy-analyses of PVT air collectors. Some of the published studies conducted on PVT air collectors during the year 2010-2019 are reported in Table 1 [16-55].

Table 1. Summary of study available on PVT air collectors in 2010-2019 [16-55]

\begin{tabular}{|c|c|c|}
\hline Year & Contents of Study & Author(s) and Reference \\
\hline 2010 & Energy-economic analysis of theoretical and experimental study & Agrawal and Tiwari $[16,17]$ \\
\hline 2010 & Energy analysis of theoretical and experimental study & Sarhaddi et al. [18] \\
\hline 2010 & Energy-exergy analysis of theoretical and experimental study & Sarhaddi et al. [19] \\
\hline 2010 & Energy analysis of theoretical and experimental study & Shahsavar and Ameri [20] \\
\hline 2011 & Energy-exergy analysis of theoretical study & Agrawal and Tiwari [21] \\
\hline 2012 & Energy analysis of theoretical study & Amori and Al-Najjar [22] \\
\hline 2012 & Energy-exergy analysis of theoretical and experimental study & Agrawal et al. [23] \\
\hline 2013 & Energy-exergy-environmental analysis of experimental study & Agrawal and Tiwari [24] \\
\hline 2013 & Energy-exergy-environmental analysis of experimental study & Rojaria et al. [25] \\
\hline 2014 & Energy analysis of theoretical and experimental study & Yang and Athienitis [26] \\
\hline 2014 & Energy analysis of experimental study & Kim et al. [27] \\
\hline 2014 & Energy analysis of experimental study & Amori and Al Raheem [28] \\
\hline 2015 & Energy analysis of theoretical and experimental study & Li et al. [29] \\
\hline 2015 & Energy analysis of experimental study & Good et al. [30] \\
\hline 2015 & Energy analysis of experimental study & Ahn et al. [31] \\
\hline 2015 & Energy-exergy-economic analysis of theoretical study & Jahromi et al. [32] \\
\hline 2015 & Energy analysis of theoretical study & Kamel and Fung [33] \\
\hline 2015 & Energy-exergy-enviro-economic analysis of theoretical study & Rajoria et al. [34] \\
\hline 2016 & Energy-exergy analysis of experimental study & Gholampour and Ameri [35] \\
\hline 2016 & Energy analysis of theoretical study & Rounis et al. [36] \\
\hline 2016 & Energy analysis of theoretical and experimental study & Mojumder et al. [37] \\
\hline 2016 & Energy-exergy analysis of theoretical and experimental study & Hazami et al. [38] \\
\hline 2016 & Energy-exergo-economic analysis of experimental study & Tiwari and Tiwari [39] \\
\hline 2016 & Energy analysis of theoretical and experimental study & Slimani et al. [40] \\
\hline 2016 & Energy analysis of theoretical and experimental study & Tabet, et al. [41] \\
\hline 2017 & Energy and exergy analysis of theoretical study & Ooshaksaraei et al. $[42,43]$ \\
\hline 2017 & Energy analysis of theoretical study & Zohri et al. [44] \\
\hline 2017 & Energy analysis of experimental study & Zohri et al. [45] \\
\hline 2018 & Energy and exergy analysis of theoretical study & Zohri et al. [46] \\
\hline 2018 & Exergy analysis of theoretical study & Zohri et al. [47] \\
\hline 2018 & Energy and exergy analysis of experimental study & Das et al. [48] \\
\hline 2018 & Energy-exergy analysis of theoretical and experimental study & Fudholi et al. [49] \\
\hline 2018 & Energy-economic analysis of theoretical study & Nazri et al. [50] \\
\hline 2018 & Energy analysis of theoretical study & Nazri ael al. [51] \\
\hline 2018 & Energy analysis of experimental study & Nazri et al. [52] \\
\hline 2018 & Energy analysis of theoretical and experimental study & Nazri et al. [53] \\
\hline 2019 & Energy and exergy analysis of theoretical study & Abdullah et al. [54] \\
\hline 2019 & Exergy analysis of theoretical and experimental study & Fudholi et al. [55] \\
\hline
\end{tabular}

Int J Pow Elec \& Dri Syst Vol. 10, No. 4, Dec 2019 : 2037 - 2045 
Recently, Fudholi et al. [55] studied theoretical and experimental on energy and exergy analysis of PVT air collector with different mass flow rate and intensity. Fudholi et al. [56], [57] reviewed energy and exergy analysis for PVT air collectors. In 2018, PVT air collectors were reviewed in detail [58], [59].

\section{TYPES OF PVT AIR COLLECTORS}

PVT is the popular system of a solar energy system. PVT air collector is designed to receive solar energy and convert it into electrical and hot air (thermal); in this device, thermal is transferred into air that flows into the collector. A PVT air collector consists of a PV panel, an insulation and a frame as well as one or more glass cover (Figure 1A) or a transparent material placed over the absorbing plate with air flowing around it. The efficiency of PVT air collectors can be enhanced by using extended heat transfer area through the absorber with finned absorbers (Figure 1B), corrugated surfaces (Figure 1C), porous media (Figure 1D) and honeycomb absorber (Figure 1I). PVT air collectors can be categorised into four types are: (i) conventional PVT air collector, which single-pass with a channel below a PV panel or known as back-pass PVT air collector (Figure 1A), (ii) PVT air collector with extended heat transfer area (Figure 1A, B, C, I), (iii) with thermal sorage (Figure 1E, J), and (iv) hybrid PVT air collector (Figure 1F, G, H). Figure 1F shows the combination of thermoelectric modules with PVT air collector. Figure $1 \mathrm{G}$ and Figure $1 \mathrm{H}$ shows the combination air-water/nanofluids-based PVT collector.

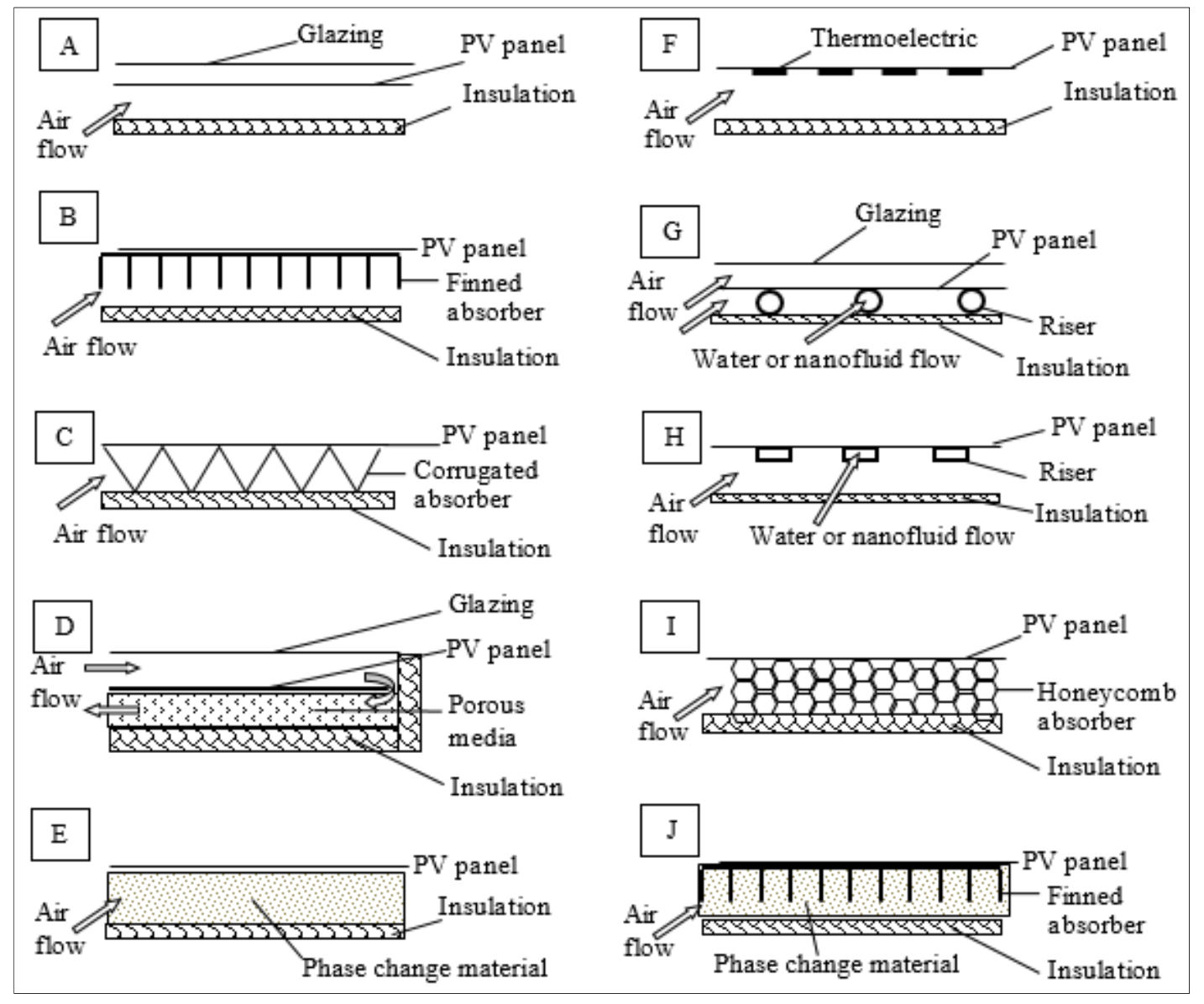

Figure 1. Various types of flat-plate PVT air collectors

\section{STUDIES CONDUCTED ON DUAL CHANNEL PVT AIR COLLECTORS}

Several studies conducted on the energy and exergy analyses of dual channel PVT air collectors as shown in Table 2. Hegazy [60] comprehensively investigated the overall performances of PVT air collectors. This investigation was based on single glazing collectors, where air flows over the absorber (Model I) or 
below it (Model II) and on both sides of the absorber in a single pass (Model III) or in a double pass (Model IV). The results concluded that for a given collector design, the temperature of the PV decreases due to an increase in flow rate, thereby improving the electrical efficiency of the collector. Among the four PVT models, Model 1 displayed the lowest overall performance, whereas Model III exhibited the highest overall performance, followed by Model IV. For Model III (known as single-pass dual channel PVT air collector, as shown in Figure 2), they reported that PV, thermal and PVT efficiencies of $6.9 \%-8.1 \%, 30 \%-56 \%$ and $34.3 \%-61.4 \%$, respectively. Shahsavar et al. [61] studied energy and exergy analyses of a dual channel PVT air collector with and without glass cover. For the glazed system, it is found that PV, thermal, and PVT energy efficiencies of $8.1 \%-9.1 \%, 31.6-36.2 \%$, and $39.8 \%-44.9 \%$, respectively, during the day where as PV, thermal, PVT Exergy efficiencies of $3.9 \%-6.7 \%, 0.9 \%-1.1 \%$, and $4.8 \%-7.7 \%$, respectively. For the unglazed system, it is evident that there are variations of PV, thermal, and PVT energy efficiencies of $9.6 \%-$ $10.6 \%, 12.2 \%-24.8 \%$, and $22.5 \%-34.6 \%$, respectively, during the day where as PV, thermal and PVT Exergy efficiencies of $5.7 \%-8.7 \%, 0.3 \%-0.5 \%$, and $6 \%-9 \%$, respectively. Shan et al. [62] also investigated several of PVT air collecotors. They established energy balance equations and mathematical models of PVT air collectors with glass cover for five cases. They reported that for single-pass dual channel PVT air collector (Case 4), PV and thermal efficiencies of 4.7\%\%-5.7\% and 59\%-61\%, respectively. Amori and Abd-AlRaheem [63] studied various PVT air collectors. They reported that for single-pass dual channel PVT air collector, PV and thermal efficiencies of 5\%-12\% and 58\%-77\%, respectively. Sing et al [64] proposed dual channel semitransparent photovoltaic thermal (DCSPVT). They presented that PV efficiency and PVT Exergy efficiency of $\sim 12 \%-16 \%$ and $22 \%-58 \%$, respectively. Ooshaksaraei et al. [65] developed four new designs of PVT air collectors with bifacial solar cells. In Model IV, the air flows between the glazing and the PV lamination and returns back to the second channel. For Model IV, they reported that energy and exergy efficiencies range from $51 \%$ to $67 \%$ and from $3.9 \%$ to $9.5 \%$, respectively.



Figure 2. Schematic of single-pass dual channel PVT air collector

Table 2. Studies conducted on energy and exergy analysis of dual channel PVT air collectors

\begin{tabular}{|c|c|c|c|c|c|}
\hline Reference & Study & \multicolumn{3}{|c|}{ Energy efficiency (\%) } & PVT \\
\hline \& year & & PV & Thermal & PVT & exergy efficiency \\
\hline [60], 2000 & Theoretical & $6.9-8.1$ & $30-56$ & $34.3-61.4$ & - \\
\hline$[61], 2012$ & $\begin{array}{l}\text { Theoretical and } \\
\text { experimental }\end{array}$ & $8.1-10.6$ & $12.2-36.2$ & $22.5-44.9$ & $4.8-9$ \\
\hline [62], 2014 & Theoretical & $4.7-5.7$ & $59-61$ & - & - \\
\hline$[63], 2014$ & $\begin{array}{l}\text { Theoretical and } \\
\text { experimental }\end{array}$ & $5-12$ & $58-77$ & - & - \\
\hline$[64], 2016$ & $\begin{array}{l}\text { Theoretical and } \\
\text { experimental }\end{array}$ & $12-16$ & - & - & $22-58$ \\
\hline$[65], 2017$ & $\begin{array}{l}\text { Theoretical and } \\
\text { experimental }\end{array}$ & - & - & $51-67$ & $3.9-9.5$ \\
\hline
\end{tabular}

\section{MATHEMATICAL MODEL OF DUAL CHANNEL PVT AIR COLLECTORS}

Shahsavar et al. [61] analysed the energy and exergy performances of a naturally ventilated PVT air collector in Kerman, Iran. A thin metal sheet was used as a collector to improve the heat extraction of the PV panel and increase the thermal and electrical outputs. The energy balance of this PVT air collector, as shown in Figure 3, is expressed as follows.

For the glass cover:

$$
\alpha_{g} I A d x=\left(h_{r, p v g}+h_{c}\right)\left(T_{g}-T_{p v}\right) A d x+\left(h_{r, g s}+h_{w}\right)\left(T_{g}-T_{a}\right) A d x
$$

For the PV panel: 


$$
\begin{aligned}
& \tau_{g} \alpha_{p v}\left(1-\eta_{p v}\right) I A d x=h_{p v a}\left(T_{p v}-T_{a}\right) A d x+h_{p v f 1}\left(T_{p v}-T_{f 1}\right) A d x \\
& +h_{r, p v p}\left(T_{p v}-T_{p}\right) A d x
\end{aligned}
$$

For the upper air channel:

$$
\dot{m}_{f 1} C_{p} d T_{f 1}=h_{p v f 1}\left(T_{p v}-T_{f 1}\right) A d x+h_{p f 1}\left(h_{p}-T_{f 1}\right) A d x
$$

For the thin metal sheet:

$$
h_{r, p v p}\left(T_{p v}-T_{p}\right) A d x=h_{p f 1}\left(T_{p}-T_{f 1}\right) A d x+h_{p f 2}\left(T_{p}-T_{f 2}\right) A d x+h_{r, p b}\left(T_{p}-T_{b}\right) A d x
$$

For the lower air channel:

$$
\dot{m}_{f 2} C_{p} d T_{f 2}=h_{p f 2}\left(T_{p}-T_{f 2}\right) A d x+h_{b f 2}\left(h_{b}-T_{f 2}\right) A d x
$$

For the back insulation:

$$
h_{r, p b}\left(T_{p}-T_{b}\right) A d x=U_{b}\left(T_{b}-T_{a}\right) A d x+h_{b f 2}\left(T_{b}-T_{f 2}\right) A d x
$$

For the unglazed type:

$$
\alpha_{p v}\left(1-\eta_{p v}\right) I A d x=h_{w}\left(T_{p v}-T_{a}\right) A d x+h_{p v f 1}\left(T_{p v}-T_{f 1}\right) A d x+h_{r, p v p}\left(T_{p v}-T_{p}\right) A d x
$$

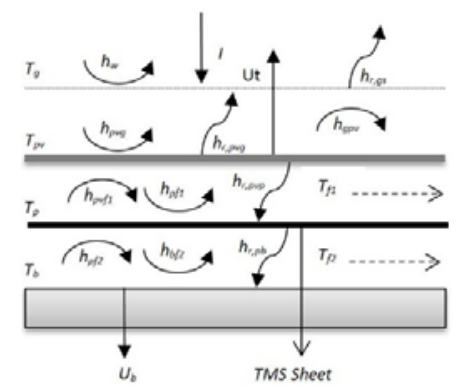

Figure 3. Schematic of a PVT air collector with temperatures and heat transfer coefficients

Singh et al. [64] analysed the thermal modelling and performance of a two-channel, semitransparent PVT system. The overall efficiency performance of the two-inlet, semi-transparent PVT was higher than the one-pass semi-transparent PVT system. The energy balance of this PVT air collector, as shown in Figure 4, is expressed as follows.

For the top glass channel:

$$
U_{p v f 1}\left(T_{p v}-T_{f 1}\right) b d x=\dot{m}_{f 1} C_{f 1} \frac{d T_{f 1}}{d x}+U_{t}\left(T_{p v}-T_{a}\right) b d x
$$

Where

$$
h_{p v f 1}=\left[\frac{L_{g}}{k_{g}}+\frac{1}{h_{f 1}}\right]^{-1} \text { And } U_{t}=\left[\frac{L_{g}}{k_{g}}+\frac{1}{h_{p v a}}\right]^{-1} .
$$

For the PV panel:

$$
\alpha_{c} \tau_{g}^{2} I \beta_{c} b d x=h_{p v f 1}\left(T_{p v}-T_{f 1}\right) b d x+h_{p v f 2}\left(T_{p v}-T_{f 2}\right) b d x+\eta_{p v} \alpha_{g}^{2} F I b d x,
$$

Where

$$
U_{p v f 1}=\left[\frac{L_{g}}{k_{g}}+\frac{1}{h_{f 1}}\right]^{-1} .
$$


For the down air channel:

$$
U_{p v f 2}\left(T_{p v}-T_{f 2}\right) b d x+h_{p f 2}\left(T_{p}-T_{f 2}\right) b d x=\dot{m}_{f 2} C_{f 2} \frac{d T_{f 2}}{d x}+U_{f 2 a}\left(T_{f 2}-T_{a}\right) b d x
$$

Where

$$
U_{f 2 a}=\left[\frac{L_{p}}{k_{p}}+\frac{L_{I}}{k_{I}}+\frac{1}{h_{I}}\right]^{-1}
$$

For the blackened absorbing plate:

$$
\alpha_{p} \tau_{g}^{3} I(1-F) b d x=h_{p f 2}\left(T_{p}-T_{f 2}\right) b d x+U_{b}\left(T_{p}-T_{a}\right) b d x
$$

Where

$$
U_{b}=\left[\frac{L_{I}}{k_{I}}+\frac{1}{h_{I}}\right]^{-1}
$$

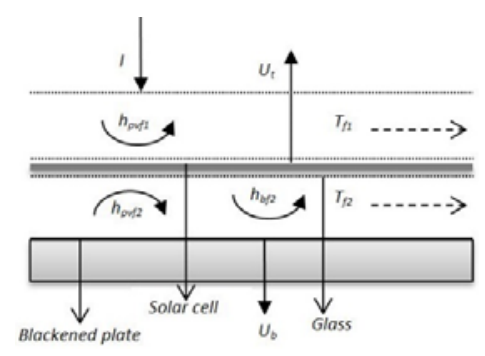

Figure 4. Schematic of the two-inlet, semi-transparent PVT system with temperatures and heat transfer coefficients

Ooshaksaraei et al. [65] analysed the energy and exergy of dual channel PVT air collectors as shown in Figure 5(a). Figure 5(b) shows the various heat transfer coefficients of the dual channel PVT air collector considered. An energy balance model was developed to analyse the performance. The energy balance equations for dual channel PVT air collector can be expressed as follows.

For the glass cover:

$$
S \alpha_{G}+h_{r L g}\left(T_{L}-T_{g}\right)=h_{c g a}\left(T_{g}-T_{a}\right)+h_{c g f 1}\left(T_{g}-T_{f 1}\right)+h_{r g s}\left(T_{g}-T_{s}\right)
$$

For the PV laminate:

$$
\begin{aligned}
& S \tau_{g} \alpha_{P V} P\left(1-\eta_{P V_{\text {front }}}\right)+S \tau_{g} \tau_{L}(1-P) \eta_{R} P \alpha_{P V}\left(1-\eta_{P V_{r e a r}}\right)=h_{c L f 1}\left(T_{L}-T_{f 1}\right)+ \\
& h_{r L g}\left(T_{L}-T_{g}\right)+h_{c L f 2}\left(T_{L}-T_{f 2}\right)+h_{r L R}\left(T_{L}-T_{R}\right)
\end{aligned}
$$

For the reflector:

$$
h_{r L R}\left(T_{L}-T_{R}\right)+S(1-P) \tau_{L}\left(1-\eta_{R}\right) \tau_{g}=h_{c R f 2}\left(T_{R}-T_{f 2}\right)+U_{R}\left(T_{R}-T_{a}\right)
$$

For fluid 1:

$$
h_{c g f 1}\left(T_{g}-T_{f 1}\right)+h_{c L f 1}\left(T_{L}-T_{f 1}\right)=\frac{m C_{f 1}}{b} \frac{d T_{f 1 i}}{d x_{f 1 i}}
$$

For fluid 2:

$$
h_{c L f 2}\left(T_{L}-T_{f 2}\right)+h_{c R f 2}\left(T_{R}-T_{f 2}\right)=\frac{m C_{f 2}}{b} \frac{d T_{f 2 i}}{d x_{f 2 i}}
$$




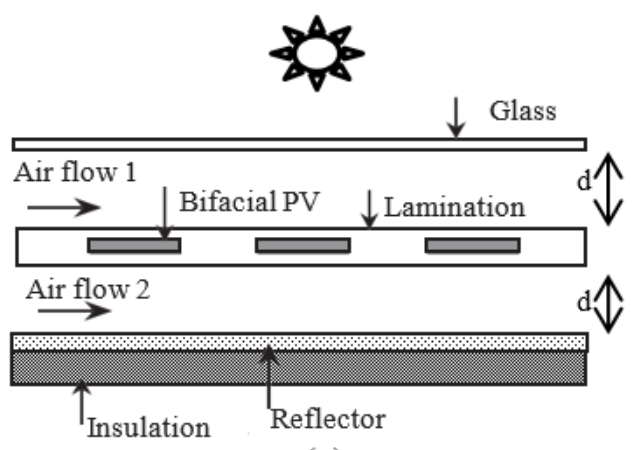

(a)

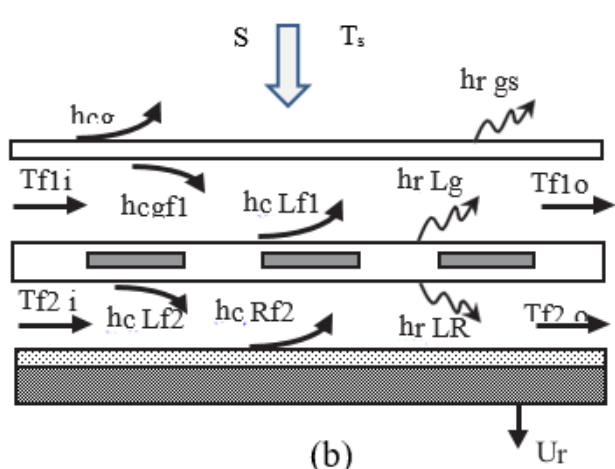

(b)

Figure 5. (a) Schematic of a dual channel PVT air collector, (b) with temperatures and heat transfer coefficients

\section{CONCLUSIONS}

PVT air collector is used to remove heat accumulated in a PV panel and reuses the waste heat in an appropriate way. PVT air collector combines the PV panel and solar collector into a single module, thereby enabling PV-cell cooling and simultaneously utilising the extracted heat for domestic use. Heat transfer and thermal modelling of dual channel PVT air collectors are presented. Generally, steady-state one-dimensional linear first-order differential equations were reported for solution of mathematical model. Energy and exergy efficiencies of dual channel PVT air collectors were $22.5 \%-67 \%$ and $3.9 \%-58 \%$, respectively.

\section{ACKNOWLEDGEMENTS}

We gratefully acknowledge the funding from USAID through the SHERA program-Centre for Development of Sustainable Region (CDSR). In year 2017-2021 CDSR is led by Center for Energy Studies-UGM.

\section{REFERENCES}

[1] N.F.M. Razali, et al., "Experiment study of water based photovoltaic-thermal (PV/T) collector," International Journal of Electrical and Computer Engineering (IJECE), vol. 9, no. 1, pp. 118-125, 2019.

[2] N.F.M. Razali, et al., "Review of water-nanofluid based photovoltaic/thermal (PV/T) systems," International Journal of Electrical and Computer Engineering (IJECE), vol. 9, no. 1, pp. 134-140, 2019.

[3] N.S.B. Rukman, et al., "Energy and exergy efficiency of water-based photovoltaic thermal (PVT) systems: an overview," International Journal of Power Electronics and Drive Systems (IJPEDS), vol. 10, no. 2, pp. 987-994, 2019.

[4] A. Fudholi, et al., "Review on exergy and energy analysis of solar air heater," International Journal of Power Electronics and Drive Systems (IJPEDS), vol. 9, no. 1, pp. 420-26, 2018.

[5] A. Fudholi, et al., "Review on solar collector for agricultural produce," International Journal of Power Electronics and Drive Systems (IJPEDS), vol. 9, no. 1, pp. 414-19, 2018.

[6] A. Fudholi, et al., "R\&D of photovoltaic thermal (PVT) systems: an overview," International Journal of Power Electronics and Drive Systems (IJPEDS), vol. 9(2), pp. 803-10, 2018.

[7] A. Fudholi, et al., "Primary study of tracking photovoltaic system for mobile station in Malaysia," International Journal of Power Electronics and Drive Systems (IJPEDS), vol. 9(1), pp. 427-32, 2018.

[8] A. Fudholi, et al., "Design and testing of solar dryer for drying kinetics of seaweed in Malaysia," in Proc. of the 5th Int. Conf. on Energy and Development- Environment - Biomedicine (EDEP'11, Corfu, 2011, pp. 119-124.

[9] C.N. Aisyah et al., "Kecekapan pengumpul PV/T menggunakan pengumpul terma reka bentuk pilin (Efficiency of PV/T collector using spiral thermal absorber design)," Sains Malaysiana, vol. 47, no. 4, pp. 853-859, 2018.

[10] A. Fudholi, et al., "Energy analysis and improvement potential of finned double-pass solar collector," Energy Conversion and Management, vol. 75, pp. 234-40, 2013.

[11] A. Fudholi, et al., "Performance and cost benefits analysis of double-pass solar collector with and without fins," Energy Conversion and Management, vol. 76, pp. 8-19, 2013.

[12] A. Fudholi, et al., "Collector efficiency of the double-pass solar air collectors with fins," Proceedings of the 9th WSEAS International Conference on SYSTEM SCIENCE and SIMULATION in ENGINEERING (ICOSSSE'10), Japan, 2010, pp. 428-34.

[13] A. Fudholi, et al., "Experimental Study of the double-pass solar air collector with staggered fins," Proceedings of the 9th WSEAS International Conference on SYSTEM SCIENCE and SIMULATION in ENGINEERING (ICOSSSE'10), Japan, 2010, pp. 410-14. 
[14] J.K. Tonui and Y. Tripanagnostopoulos, "Performance improvement of PV/T solar collectors with natural air flow operation," Solar Energy, vol. 82, pp. 1-12, 2008.

[15] J.K. Tonui and Y. Tripanagnostopoulos, "Air-cooled PV/T solar collectors with low cost performance improvements," Solar Energy, vol. 81, pp. 498-511, 2007.

[16] B. Agrawal and G.N. Tiwari, "Life cycle cost assessment of building integrated photovoltaic thermal (BIPVT) systems," Energy and Buildings, vol. 42, pp. 1472-81, 2010.

[17] B. Agrawal and G.N. Tiwari, "Optimizing the energy and exergy of building integrated photovoltaic thermal (BIPVT) systems under cold climatic conditions," Applied Energy, vol. 87, pp. 417-26, 2010.

[18] F. Sarhaddi, et al., "An improved thermal and electrical model for a solar photovoltaic thermal (PV/T) air collector," Applied Energy, vol. 87, pp. 2328-39, 2010.

[19] F. Sarhaddi, et al., "Exergetic performance assessment of a solar photovoltaic thermal (PV/T) air collector," Energy and Buildings, vol. 42, pp. 2184-99, 2010.

[20] A. Shahsavar, and M. Ameri, M., "Experimental investigation and modeling of a direct-coupled PV/T air collector," Solar Energy, vol. 84(11), pp. 1938-1958, 2010.

[21] S. Agrawal, and G.N. Tiwari, "Energy and exergy analysis of hybrid micro-channel photovoltaic thermal module," Solar Energy, vol. 85(2), pp. 356-370, 2011.

[22] K.E. Amori, and H.M.T. Al-Najjar, "Analysis of thermal and electrical performance of a hybrid (PV/T) air based solar collector for Iraq," Applied Energy, vol. 98, pp. 384-95, 2012.

[23] S. Agrawal, et al., "Indoor experimental analysis of glazed hybrid photovoltaic thermal tiles air collector connected in series," Energy and Buildings, vol. 53, pp. 145-51, 2012.

[24] S. Agrawal, and G.N. Tiwari, "Overall energy, exergy and carbon credit analysis by different type of hybrid photovoltaic thermal air collectors," Energy conversion and Management, vol. 65, pp. 628-636, 2013.

[25] C.S. Rajoria, et al., "Exergetic and enviroeconomic analysis of novel hybrid PVT array," Solar Energy, vol. 88, pp. 110-19, 2013.

[26] T. Yang and A. K. Athienitis, "A study of design options for a building integrated photovoltaic/thermal (BIPV/T) system with glazed air collector and multiple inlets," Solar Energy, vol. 104, pp. 82-92, 2014.

[27] J.H. Kim, S.H. Park, and J.T. Kim, "Experimental performance of a photovoltaic-thermal air collector," Energy Procedia, vol. 48, pp. 888-894, 2014.

[28] K.E. Amori, M.A. Abd-AlRaheem, "Field study of various air based photovoltaic/thermal hybrid solar collectors," Renewable Energy, vol. 63, pp. 402-14, 2014.

[29] Y. Li, et al., "Performance study of a solar photovoltaic air conditioner in the hot summer and cold winter zone," Solar Energy, vol. 117, pp. 167-79, 2015.

[30] C. Good, et al., "Solar energy for net zero energy buildings - A comparison between solar thermal, PV and photovoltaic-thermal (PV/T) systems," Solar Energy, vol. 122, pp. 986-96, 2015.

[31] J.G. Ahn, et al., "A Study on Experimental Performance of Air-Type PV/T Collector with HRV," Energy Procedia, vol. 78, pp. 3007-12, 2015.

[32] S.N. Jahromi, A. Vadiee, and M. Yaghoubi, "Exergy and economic evaluation of a commercially available PV/T collector for different climates in Iran," Energy Procedia, vol. 75, pp. 444-456, 2015.

[33] R.S. Kamel, and A.S. Fung, "Modelling and Characterization of Transparent Building Integrated PV/T Collector," Energy Procedia, vol. 78, pp. 1871-1876, 2015.

[34] C.S. Rajoria, et al., "Exergetic and enviroeconomic analysis of semitransparent PVT array based on optimum air flow configuration and its comparative study," Solar Energy, vol. 122, pp. 1138-45, 2015.

[35] M. Gholampour and M. Ameri, "Energy and exergy analyses of photovoltaic/thermal flat transpired collectors: Experimental and theoretical study," Applied Energy, vol. 164, pp. 837-56, 2016.

[36] E.D. Rounis, A.K. Athienitis, and T. Stathopoulos, "Multiple-inlet building integrated photovoltaic/thermal system modelling under varying wind and temperature conditions," Solar Energy, vol. 139, pp. 157-170, 2016.

[37] J.C. Mojumder, et al., "An experimental investigation on performance analysis of air type photovoltaic thermal collector system integrated with cooling fins design," Energy and Buildings, vol. 130, pp. 272-285, 2016.

[38] M. Hazami, et al., "Energetic and exergetic performances analysis of a PV/T (photovoltaic thermal) solar system tested and simulated under to Tunisian (North Africa) climatic conditions," Energy, vol. 107, pp. 78-94, 2016.

[39] S. Tiwari and G. N. Tiwari, "Exergoeconomic analysis of photovoltaic-thermal (PVT) mixed mode greenhouse solar dryer," Energy, vol. 114, pp. 155-164, 2016.

[40] M.E.A. Slimani, et al., "Study and modeling of energy performance of a hybrid photovoltaic/thermal solar collector: Configuration suitable for an indirect solar dryer," Energy Conversion and Management, vol. 125, pp. 209-21, 2016.

[41] I. Tabet, et al., "An experimental investigation on performance analysis of air type photovoltaic thermal collector system integrated with cooling fins design," The European Physisical Journal Plus, vol. 131(41), pp. 1-15, 2016.

[42] P. Ooshaksaraei, et al., "Performance of four air-based photovoltaic thermal collectors configurations with bifacial solar cells," Renewable Energy, vol. 102, pp. 279-293, 2017.

[43] P. Ooshaksaraei, et al., "Characterization of a bifacial photovoltaic panel integrated with external diffuse and semimirror type reflectors". International Journal of Photoenergy, vol. 7, 2013.

[44] M. Zohri et al., "Photovoltaic thermal (PVT) system with and without fins collector: theoretical approach," International Journal of Power Electronics and Drive System (IJPEDS), vol. 8(4), pp. 1756-63, 2017.

[45] M. Zohri et al., "Performance analysis of photovoltaic thermal (PVT) with and without V-groove collector," Journal of Engineering and Applied Sciences, vol. 12(22), pp. 6029-6032, 2017.

Int J Pow Elec \& Dri Syst Vol. 10, No. 4, Dec 2019 : 2037 - 2045 
[46] M. Zohri et al., "Energy and exergy analysis of photovoltaic thermal (PVT) with and without fins collector," ARPN Journal of Engineering and Applied Sciences, vol. 13(3), pp. 803-, 2018.

[47] M. Zohri, et al., "Exergy assessment of photovoltaic thermal with v-groove collector using theoretical study," TELKOMNIKA (Telecommunication, Computing, Electronics and Control), vol. 16(2), pp. 550-57, 2018.

[48] B. Das, et al., "Performance analysis of single glazed solar PVT air collector in the climatic condition of NE India," Proceedings: $4^{\text {th }}$ International Electronic Confrence on Entropy and Its Application (ECEA 2017), 2018, pp. 1-14.

[49] A. Fudholi, et al., "Energy and exergy analyses of photovoltaic thermal collector with $\nabla$-groove," Solar Energy, vol. 159, pp. 742-50, 2018.

[50] N.S. Nazri, et al., "Energy economic analysis of photovoltaic-thermal-thermoelectric (PVT-TE) air collectors," Renewable and Sustainable Energy Review, vol. 92, pp. 187-97, 2018.

[51] N.S. Nazri, et al., "Mathematical modeling of photovoltaic thermal-thermoelectric (PVT-TE) air collector," International Journal of Power Electronics and Drive Systems (IJPEDS), vol. 9, no. 2, pp. 795-802, 2018.

[52] N.S. Nazri, et al., "Experimental study of photovoltaic thermal-thermoelectric (PVT-TE) air collector. International Journal of Power Electronics and Drive Systems (IJPEDS), vol. 9, no. 3, pp. 1406-1412, 2018.

[53] N.S. Nazri, et al., "Analisis tenaga sistem hibrid pengumpul udara fotovoltan terma-termoelektrik (PVT-TE)," Journal Kejuruteraan SI, vol. 1, no. 3, pp. 47-56, 2018.

[54] A.L. Abdullah, et al., "Numerical analysis of solar hybrid photovoltaic thermal air collector simulation by ANSYS," CFD Letter, vol. 11(2), pp. 1-11, 2019.

[55] A. Fudholi, et al., "Exergy and sustainability index of photovoltaic thermal (PVT) air collector: a theoretical and experimental study," Renewable and Sustainable Energy Reviews, vol. 100, pp. 44-51, 2019.

[56] A. Fudholi, et al., "Review of solar photovoltaic/thermal (PV/T) air collector," International Journal of Electrical and Computer Engineering (IJECE), vol. 9(1), pp. 126-133, 2019.

[57] A. Fudholi, et al., "Energy and exergy analysis of air based photovoltaic thermal (PVT) collector: a review," International Journal of Electrical and Computer Engineering (IJECE), vol. 9 (1), 109-117, 2019.

[58] S.S. Joshi and A.S. Dhoble, "Photovoltaic-thermal systems (PVT): technology review and future trends," Renewable and Sustainable Energy Reviews, vol. 92, pp. 848-882, 2018.

[59] S. Tiwari et al., "PVT air collector integrated greenhouse dryers," Renewable and Sustainable Energy Reviews, vol. 90, pp. 142-159, 2018.

[60] A.A. Hegazy, "Comparative study of the performance of four photovoltaic/thermal solar air collectors," Energy Conversion Management, vol. 41, pp. 861-881, 2000.

[61] A. Shahsavar, et al., "Energy and exergy analysis of a photovoltaic-thermal collector with natural air flow," Journal of Solar Energy Enggineering, vol. 34(1), pp. 110-14, 2012.

[62] F. Shan, et al., "Comparative simulation analyses on dynamic performances of photovoltaic-thermal solar collectors with different configurations," Energy Conversion and Management, vol. 87, pp. 778-786, 2014.

[63] K.E. Amori and M.A. Abd-AlRaheem, "Field study of various air based photovoltaic/thermal hybrid solar collectors," Renewable Energy, vol. 63, pp. 402-414, 2014.

[64] S. Singh, et al., "Design, modeling and performance analysis of dual channel semitransparent photovoltaic thermal hybrid module in the cold environment," Energy Conversion and Management, vol. 114, pp. 241-250, 2016.

[65] P. Ooshaksaraei, et al., "Performance of four air-based photovoltaic thermal collectors configurations with bifacial solar cells," Renewable Energy, vol. 102, pp. 279-293, 2017. 